\title{
Notes on the Conducting Tissue-System in Bryophyta.
}

BY

\author{
A. G. TANSLEY, M.A., \\ Assistant Professor of Botany,
}

AND

EDITH CHICK, B.Sc.,

Quain Student in Botany, University College, London.

\section{With Plates I and II.}

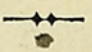

\section{INTRODUCTORY.}

$\mathrm{T}^{\mathrm{T}}$ was in $\mathrm{I} 8 \mathrm{I} 3$ that $\mathrm{A}$. P. de Candolle separated the groups 1 we now call Pteridophyta and Phanerogamia under the common name of Vasculares from the Cellulares (Bryophyta and Thallophyta). Although the term 'vascular plant' (Gefässpflanze) has lost in the light of modern anatomical knowledge its literal significance as applied to plants containing vessels formed by the fusion of cells, it is still commonly and usefully applied to the Pteridophytes and Phanerogams as possessing a double conducting or 'vascular' system of well-differentiated type. In this, two definite tissueelements-the tracheid and the sieve-tube-are the respective essential components of the two conducting tissues-the

[Annals of Botany, Vol. XV. No. LVII. March, I gor.] 
xylem and phloem. All the members of these two highest groups of plants, except perhaps a few doubtful cases among the lower Pteridophytes, possess such a differentiated conducting system, or can clearly be shown to have lost it by degeneration.

In the Bryophyta this is not the case. Though (unlike the green Thallophyta) the great majority are land-plants, yet nearly all the Liverworts and several of the Mosses have no specialized conducting system, nor is there any reason to suppose that their ancestors ever had. But the exigencies of increasing bulk, and particularly of the erect habit, have led, in a few of the Liverworts and the majority of the Mosses, to the acquirement of a conducting system, which, while it is extremely simple in most cases, attains in the highest forms (Polytrichaceae) to a complexity not only distinctly surpassing that of the simplest true vascular plants but almost comparable with that found among highly developed Phanerogams. Now it is almost as certain as any phylogenetic thesis is likely to be, that the conducting tissues of Bryophytes have nothing directly to do with the origin of the conducting tissues of the higher plants. The main seat of the development of these tissues in Bryophytes is the gametophyte generation, which is in any case excluded from the comparison, since the vascular system in Pteridophytes is confined to the sporophyte. And at the least it is extremely unlikely that the Pteridophytes have been derived from a Bryophytic ancestor with a sporophyte showing anything approaching the specialization of the moss-sporogonium, in which conducting tissues also occur. But it must not for this reason be supposed that the Bryophytes are of no interest in considering the problem of the evolution of the vascular system in Pteridophytes. We see among the former group, plants in the very act, so to speak, of developing a conducting system in response to vital needs, and others in the most various stages of its evolution in complexity. The conditions under which this evolutionary development occurred must have been practically identical with those to which the primitive Pteridophytic sporophyte was subjected-gradually. 
increasing adaptation of a simple leafy form to terrestrial life. And the final result, as seen in the highest Polytrichaceae, is so strikingly like, even in many details, the state of things obtaining in the true vascular plant, as to furnish probably one of the completest and most interesting cases of homoplastic development in the plant-kingdom. It can hardly therefore be denied that the study of the conducting system in Mosses is calculated to throw most valuable sidelights on the question of the evolution of the vascular systems of the higher plants.

Vaizey ${ }^{1}$ has already investigated the conducting tissues of the sporogonium of Mosses with the object of throwing light on the evolution of these tissues among the vascular plants, but he was under the influence, as it seems to us, of curiously narrow and misleading morphological doctrine. He sets on one side the tissues of the gametophyte of the Bryophyta, since according to the antithetic theory of alternation of generation the plant-body in which they are developed is not homologous with the plant of the Vasculares, and goes on to claim that 'every one will admit that the tissues of the sporophyte of the Muscineae are homologous with those of the sporophyte of the Vasculares' (p. 275). He thus implicitly assumes not only that the sporophyte of the Pteridophytes has been evolved from a Bryophytic sporogonium, but that its differentiated tissue-systems have been evolved from the differentiated tissue-systems of the highly specialized mosssporogonium, an assumption so extremely improbable that it may be dismissed without discussion. In our opinion, while there can be no question of homology in either case, the conducting tissues of the Bryophytic gametophyte are at least as instructive as those of the sporogonium from this point of view of comparison, first because foliage-leaf structures are involved, and secondly because in the Polytrichaceae at least, there is a rhizome which is physiologically and histologically a root, directly continuous with the aerial

${ }^{1}$ Journ. Linn. Soc. Bot., vol. xxiv, $1887-8$.

B 2 
stem and thus comparable with the primary root in Pteridophytes.

It is to Haberlandt's admirable work on the Anatomy and Physiology of the Mosses that we owe the great bulk of our knowledge on this subject. He not only discovered most of the important facts but gave them a clear interpretation in the light of evolutionary theory. The following notes are intended to supplement his work, both in the further elucidation of points in the histology of Bryophytic conducting systems, and in the discussion of the various evolutionary problems involved.

\section{The Conducting Strands of Liverworts.}

The great majority of Liverworts, as is well known, have no differentiated water-conducting tissues. Living, as many of them do, in constantly damp situations, or flourishing only during the season when they are surrounded by air with a very high relative humidity, and frequently covered with rain or dew, they are used to absorbing water over their whole surface. A certain number no doubt depend for their water supply, at least at certain periods, on what is absorbed through the rhizoids which fix the thallus to the substratum, but the whole of the under-surface is commonly provided with these rhizoids, and the entire body is seldom too large to admit of the ready conduction of the water so absorbed through the ordinary parenchyma-cells to every part of the plant.

In a certain number of cases, however, among the thalloid forms, either assimilating parts of the thallus (Pallavicinia, Symphyogyna, Hymenophyton), or specialized reproductive branches (Marchantiaceae), are raised considerably above the substratum, and then special means are often adopted to facilitate the conduction of water to these remote parts. It is not our intention to review the various adaptations in question, but rather to confine ourselves to the consideration of one of them-the differentiation of a definite conducting strand. 
The occurrence of a strand of elongated lignified thickwalled cells in the midst of a Liverwort-thallus was first discovered by Sir William Hooker (British Jungermanniae I 8I6) in Fungermannia (now Pallavicinia) Lyellii. Gottsche ${ }^{1}$, in 1864 , describes a similar strand in Symphyogyna sinuata, $\mathrm{N}$. et M., and states that there are often two such nerves at the base of the frond, which run parallel for some distance and often diverge at the first bifurcation of the thallus. He found that the strands had no connexion with the 'receptacles' on which the sexual organs were seated. Leitgeb in Heft 3 of his classical 'Untersuchungen über die Lebermoose' describes the cells of this strand in Symphyogyna, and states that Blyttia (Pallavicinia) and Umbraculum (Hymenophyton) have similar strands. He mentions the interesting fact that in the common formation of adventitious branches from the ventral side of the frond in these genera, the strand of the branch is discontinuous with the strand of the parent frond. He describes the cells of the strand as being elongated with pointed ends and fairly thick walls, provided with close-set 'pores,' which are arranged in spiral lines round the walls, so as to give the impression of spiral thickening on casual examination of a longitudinal section. Haberlandt ${ }^{2}$ refers to Leitgeb's descriptions, and expresses the opinion that the strand in question may very probably possess both a mechanical and a water-conducting function. Spruce ${ }^{3}$ describes and figures a new species of Symphyogyna from Dominica, which he names $S$. trivittata on account of the three strands running parallel in the midrib of the thallus. Sometimes there are only two in the upper parts, owing to the running off without branching of one of the three at a bifurcation, in the same way as in $S$. simuata.

Farmer ${ }^{4}$, in a study of Pallavicinia decipiens, Mitten, describes the strand of the rhizome of this plant as consisting of

1 Triana and Planchon's Prodromus Floræ Novo-Granatensis. Ann. Sci. Nat., $5^{\circ}$ sér., tome i, p. 182 .

${ }^{2}$ Beiträge zur Anatomie und Physiologie der Laubmoose, I886, p. 378 , note.

3 Hepaticæ Elliotianæ, Journ. Linn. Soc., vol. xxx, 1893-5.

4 Studies in Hepaticae. Annals of Botany, viii, I894. 
' fibrous cells whose walls become much thickened, and exhibit a number of shallow pits on their walls, at first view resembling ordinary striation.' $\mathrm{He}$ also calls attention to the discontinuity of the axile strands of the branches with that of the mother-axis, and explains it developmentally by reference to the fact that the apical cell of a branch, after cutting off a few segments which form short broad cells, remains dormant for some time before continuing its development. It is only after the resumption of growth that the inner cells of its segments undergo the frequent longitudinal divisions which result in the formation of the cells of the axile strand. Hence the latter is always separated from that of the mother-axis by the first-formed broad cells.

In the hope of obtaining some information as to the conditions of the evolution of primitive vascular systems, we have investigated representatives of all three of the genera in question (the only Liverworts in which these strands have as yet been found), and though our observations are not so complete as we could desire, partly owing to the difficulty of getting sufficient and satisfactory material, but even more because of the impossibility of making a study of these plants in their homes - they are very scattered and nearly all tropical forms-yet the results seem worth putting together in this place.

Of the three genera Pallavicinia, Steph., Symphyogyna, Nees et Mont., and Hymenophyton, Steph., the two first are placed by Schiffner ${ }^{1}$ in the Leptotheceae, the last in the Metzgerioideae, neighbouring families of Jungermanniaceae Anakrogynae. They differ in well-marked characters connected with the position and investment of the sporogonium, and it is perhaps most probable that the striking character they have in common-the possession of an axial strand-has developed independently in each genus. Each of the three genera, too, may be divided into two sections, of which one, presumably the more primitive, contains species with an undifferentiated thin flat and creeping thallus, while in the other the thallus

\footnotetext{
Engler and Prantl's Pflanzenfamilien, i, 3 (Hepaticae), I 893.
} 
has a creeping rhizome-like isodiametric basal part, and from it arise the flat assimilating fronds, each of which is often spread out by repeated shortened dichotomy into the shape of a fan. Farmer (op. cit.) has pointed out the probability of the parallel development of this habit in the different genera.

Of the less differentiated species of Pallavicinia, Schiffner separates two, $P$. Blyttii and $P$. hibernica, from the others, by reason of their having no axial strand in the midrib (subgenus Mörckia, Gottsche gen.). Of these the latter, as originally described by Hooker (op. cit., Plate LXXVIII), is mainly separable from $P$. Lyellii, the other British species, by this character, but there seem to be several distinct forms confused under the name Hibernica. In specimens from Hooker's type from Loughbray, Co. Wicklow, and in specimens from Yorkshire, of quite different habit, which Mr. W. H. Pearson tells us agree with Gottsche's Mörckia hibernica we have found the tissue of the midrib quite homogeneous without any trace of an axial strand. In another plant, however, kindly sent us by Mr. David McArdle of the Royal Glasnevin Botanic Gardens, from sandy flats at Malahide, Co. Dublin, under the same name, but which he places under var. $\beta$, Wilsoniana, Carrington, we find two distinct lateral strands in the midrib, each consisting, in transverse section, of about twenty cells which do not differ from the surrounding tissue in width or in the thickness of their walls. These walls, however, are distinctly brown in the unstained condition, and hold aniline stains more strongly than the surrounding tissue (P1. I, Fig. I). On longitudinal section many of the strand-cells do not differ greatly in shape from the neighbouring cells, but they tend to be longer, and some are of considerably greater length (Fig. 2). Occasionally a very thin colourless cross-wall may be seen, as at $a$ in Fig. 2. In none of these cells have we found nuclei, though they often possess a little contents, apparently scanty remains of protoplasm, as far as can be made out from herbarium-material.

In the absence of living material on which to experiment, we regard these strands as very primitive water-conducting 
channels. There can scarcely be a question here of mechanical function, and there seems to be no demand in this type of plant-body for a special channel for conducting formed foodsubstances, a process which is no doubt carried on efficiently enough by the cortical cells. On the other hand the position of these strands, and the fact that their walls though thin are lignified, agree perfectly with the strands found in the other members of the genus which do in fact conduct water. If the inference is sound, we have in this Malahide plant the most primitive water-conducting tissue or 'hydrom ${ }^{1}$ ' known. Whether Carrington's var. $\beta$, Wilsoniana is a good constant variety, and whether, if so, these strands are always found in it, are questions we are unable to answer. If the answer should be affirmative, the plant certainly deserves specific rank on the ground of this well-marked anatomical feature alone. If not, the conditions under which the strands appear would form the subject of an investigation of great interest.

As we could not hear of a certain locality for the cosmopolitan Pallavicinia Lyellii in this country, Professor Howe, of Columbia University, very kindly sent us living specimens from Van Cortlandt Park, New York. The thallus of this species is band-shaped and wavy, about 3 to $5 \mathrm{~mm}$. or more broad, with a thick, cushion-like midrib, .5 to $\mathrm{I} \mathrm{mm}$. in diameter. In transverse section the midrib in the specimen examined, $.5 \mathrm{~mm}$. broad and $.25 \mathrm{~mm}$. deep, is seen to be nearly flat on the dorsal surface, which is continued into the wings; these consist of a single layer of nearly cubical cells packed with chlorophyll, and forming the chief assimilating tissue. On the ventral surface the midrib is rounded, and some of its surface-cells are extended into thin-walled rhizoids, though these are not very numerous, so that in many transverse sections none are seen. The cells of the surface-layer are sniall, square in section, and full of chlorophyll; the deeper cells are variable in size and shape, several of those nearer the surface being full of chlorophyll, but most having

1 Potonié, Ueber d. Zusammensetzung der Leitbündel bei den Gefässkryptogamen. Jahrb. d. kön. bot. Gartens, Berlin, Bd. ii, I883. 
little or none. The midrib, in the not very strong specimens examined, was ten to twelve cells thick. Approximately in the centre of the rib, but rather nearer the dorsal surface, is a strand of narrow thick-walled cells, about twenty in the specimen here described (considerably more in the one represented in Fig. 3), the whole of the strand being about the width of a single large cell in the cortex of the rib. The thick walls of these cells are greyish in thin, and yellowish in fairly thick transverse sections. They appear perfectly homogeneous. In longitudinal section (Fig. 4) they are seen to be considerably elongated, and pointed at the ends, their walls being covered with small pits arranged on a spiral, making quite a small angle with the horizon. The pits are sometimes circular, but more often elongated, sometimes considerably, in the direction of the spiral. They are rather irregularly scattered over the walls, considerable areas being destitute of them. In sectional view they are seen to be perfectly normal simple pits. A $\frac{1}{12}$ inch oil immersion is needed for a clear view of their structure. Where a strand-cell abuts on a cortical cell the thinner wall of the cortical cell is seen to be quite without pits, but the adjacent wall of the strand-cell may be richly pitted (Fig. 4).

Here and there in the strand-cells, a little contents can be seen, which are no doubt the rêmains of protoplasm. All stages of the disorganization of this can be seen in longitudinal sections close to the apex. The strand-cells are formed, as might be expected, by longitudinal division of the inner cells cut off from the segment of the apical cell. They are differentiated very close to the apex.

A few experiments were made to find out whether the strand actually conducted water. A piece of the thallus was cut off, and its cut, end dipped into watery eosin, to a depth of about $3 \mathrm{~mm}$. After a certain time the lower part of the strand became visible through the cortical tissue of the midrib as a red thread. In one case it could be seen $\mathrm{I} \mathrm{cm}$. above the level of the solution in the course of 20 minutes, on a hot, sunny day; in another, on a grey, damper day, the same 
distance was traversed by the solution in the course of half an hour, while in one hour the solution was visible in the strand, $14 \mathrm{~mm}$. above the surface of the liquid. Similar results were obtained in other trials. A difficulty is introduced, however, by the running up of the eosin on the surface of the thallus, obscuring the view, and staining the tissue. The eosin also spreads very rapidly from the strand to the cortex of the midrib, so that the whole rib becomes coloured not far behind the highest level which the solution has reached in the strand. The above results are, however, sufficient to show that water certainly will rise in the strand more quickly than through the surrounding tissues, though very much more slowly than Haberlandt records for the conducting strands of the Mosses. We failed several times in getting the eosin solution to rise in the strands of newly formed upright branches which arise from the ventral surface of the midrib. This suggests that the discontinuity of their axial strands with that of the parent axis puts a real obstacle in the way of rapid conduction.

The strands of the other species of Pallavicinia, and those of Symphyogyna and Hymenophyton, agree with that of $P$. Lyellii in all essential respects. They may differ, though we have not examined enough material to be sure that such differences may not exist within a species, in the number and size of the cells, the thickness of the walls, and the number and inclination of the pits. These last characters, however, certainly vary in the same strand.

We had rather expected to find that the forms with a creeping thallus, and consequently with all their cells comparatively close to the absorbing rhizoids, would have less-developed strands than the forms with large assimilating axial fronds rising freely above a creeping rhizome. On the whole our results bear out this expectation. It is probable that more light would be obtained on such relations as these by a careful study of the plants under their natural conditions.

Of the sub-genus Mittenia (Gott.) Schiffner, in which there are stalked fronds arising from a rhizome-like base, we have examined $P$.decipiens from Ceylon, and have practically nothing 
to add to Farmer's description. Some of the hydroids, as seen under a $\frac{1}{12}$ inch oil immersion, are shown in Fig. 4, and it will be clear that the pits are simple and quite normal, not specially 'shallow.'

Symphyogyna. Schiffner gives two sections, Repentes and Evectae, according to the difference of habit already mentioned. Of the former we have examined $S$. sinuata from Trinidad, and S. Brasiliensis from an elevation of 4,000 feet in Bolivia (Figs. 5 and 6). So far as can be made out from scanty herbarium-material the former is closely adherent to the soil along the whole length of its midrib, and has numerous root-hairs all over the ventral surface of the rib, while the latter has no root-hairs along its upper parts, which are quite free. Certainly S. Brasiliensis has a very much bulkier strand than $S$. simuata, with wider thin-walled elements at the periphery, and narrow thick-walled cells in the centre. S. trivittata from Dominica has already been described and figured by Spruce (op. cit., p. $3^{6} 5$, Plate XXX). The three strands, though not individually very bulky, must afford between them a considerable conducting channel. Here there is a certain differentiation into rhizome and frond, such as one often gets in P. Lyellii (cf. Farmer, op. cit., p. 35), and no rhizoids are to be found on the frond.

Of the section Erectae we have, examined S. podophylla from the Devil's Peak, and also from Kooksbosch, S. Africa, $S$. Hymenophyllum from New Zealand, and S. rhizobola (Figs. 7 and 8), all with dichotomously branched fronds on long stalks. The frond-stalks of all three have stout strands, which may be circular or slightly flattened in the plane of the frond, and their elements are well provided with pits of the usual type. The rhizome of S. rhizobola, the ventral surface of which is covered with rhizoids (Fig. 8), has a distinctly weaker strand than the frond-stalk (Fig. 7).

Hymenophyton. H. Phyllanthus (New Zealand) has the habit of Pallavicinia Lyellii, and its somewhat flattened basal rhizome-like portion has a small compact strand (Fig. 9).

H. flabellatum (New Zealand) has a very long stalk to its 
fan-shaped frond, and this has a bulky band-shaped strand (Fig. 10), while that of the rhizome is much smaller. As in Pallavicinia decipiens, and apparently all such cases, the stalk of the frond is a direct continuation of the rhizome-axis, the rhizome itself being a sympodium, and the strand of each new member of this being discontinuous with that of the last. The base of the new strand is particularly weak, and it becomes gradually stronger as it passes up to the base of its frond-stalk.

We think it will be admitted that the facts support in a general way the theory of the water-conducting function of these strands, a bulkier strand being found wherever the axis can no longer depend directly on absorption by rhizoids.

Before we leave the Liverworts, we may refer to the striking absence, so far as is known, of anything like a waterconducting system among the very numerous and successful leafy Jungermanniaceae, the external vegetative organs of which are often so highly developed. The general explanation probably lies in the fact that practically all these forms are accustomed to absorb water at all points of their surface, which, owing to the great division of the body into leaves and leaf-lobes, is very much greater, compared with the mass of the plant, than in the thalloid forms. We even find the same thing among many of the Mosses in which no water channels exist. As Haberlandt ${ }^{1}$ has pointed out, such forms are either hydrophilous or xerophilous; in either case absorbing water over the whole surface when they do absorb it. It may be laid down as a general principle, in fact, that a specialized water-conducting channel is as a rule only developed where the region of absorption is localized.

There is, however, in at least one genus of the leafy Liverworts, and probably in others, an indication of the development of the other great form of conducting channel, which provides for the passage of formed food-substances. The case to which we allude is the strand of elongated cells forming a kind of 'midrib,' though only one cell thick, in the

\footnotetext{
1 Beiträge, pp. 389-9I.
} 
Conducting Tissue-System in Bryophyta. I 3

leaf of Diplophyllum albicans. Our attention was called to this by Schiffner's Fig. $64 \mathrm{H}$, p. I I2. The cells of the 'rib' are oblong, and at the upper end show a tendency to spread out fan-wise and come into contact with a number of the ordinary square cells of the leaf (Fig. II). The elongated cells contain less chlorophyll than the square ones, and their end-walls, as well as here and there the side ones, are irregularly pitted. Below, the cells of the rib are continuous with the similarly elongated cells of the stem. The tissue of the stem is quite homogeneous, showing no trace of a special conducting strand.

The difference between such a case as this and the strands we have been hitherto considering will be sufficiently obvious. The strand in question is no doubt to be considered as rudimentary 'Leitparenchym,' the forerunner, as Haberlandt has shown, of the leptom of the higher forms. Instead of a localization of the regions of absorption we have here a localization of the regions of assimilation, and a special need for ready removal of the products of assimilation owing to the square shape and thick walls of the assimilative cells which form the bulk of the leaf.

\section{The Histology of the Rhizome And A Ërial Stem in Polytrichum.}

Although W. P. Schimper ${ }^{1}$, Fr. Unger ${ }^{2}$, and P. G. Lorentz ${ }^{3}$ laid the foundations of our knowledge of the anatomical structure of the Mosses, Haberlandt, in his admirable work, Beiträge zur Anatomie und Physiologie der Laubmoose (Pringsh. Jahrb., I 886), was the first to give a satisfactory detailed account of the principal types of tissue-structure, and to explain their physiology, not only by acute reasoning from the anatomical data, but also to some extent by direct

\footnotetext{
${ }^{1}$ Recherches anatomiques et morphologiques sur les Mousses. Strassbourg, I 848 .

${ }^{2}$ Beiträge zur Physiologie der Pflanzen, vii, I80I.

3 Grundlinien $\mathrm{zu}$ einer vergleichenden Anatomie der Laubrnoose. Pringsh. Jahrb., vi, $186_{7}$.
} 
experiment. Subsequent observers have added comparatively little to our knowledge of the histology of the stem of the moss-gametophyte. The most important papers are Bastit's Recherches anatomiques et physiologiques sur la tige et la feuille des Mousses (Rev. Gén. de Bot., tome iii, 189I), and a contribution by Coesfeld (Bot. Zeit., 1892) bearing exactly the same title as Haberlandt's classical work. The former contains descriptions of the anatomy of the aërial stem, foliageleaves, rhizome, and scales of Polytrichum juniperinum, but while Bastit pays more attention than Haberlandt to the structure of the Polytrichaceous rhizome, and describes some important new features, he fails to connect his descriptions with Haberlandt's careful and thorough account of the minute histology of the aërial stem, with the result that our knowledge of this part of the subject is left in a vague and unsatisfactory state.

A reinvestigation of several species of Polytrichum with the object of getting a clear idea of the histology of the stem as a whole, has led to the discovery that the structure of the rhizome is considerably more complex than Bastit apparently suspected, the tissue-systems corresponding in many points with those that Haberlandt has described for the aërial stem.

Haberlandt and Bastit both described Polytrichum juniperinum, and the latter mentions that the other species are fundamentally similar. This is true in broad outline, but $P$. commune possesses distinctly better characterized and more highly differentiated tissue-systems than $P$.juniperinum, $P$. formosum, and $P$. piliferum, the other species we have investigated. For this reason it will be most convenient to describe pretty fully the features it presents, afterwards referring to the points of difference exhibited by the other species. Haberlandt (op. cit., pp. 366,368 ) drew attention to the fact that in relation to the stereom, the rhizome of Polytrichaceae has a distinctly root-like structure. As a matter of fact, the resemblance to the root of a vascular plant extends in a most striking way to nearly all the tissue-systems.

Cortex. The rhizome, which may be roughly circular in 
transverse section, but is more often triangular with rounded corners and slightly convex sides, is covered by a small-celled and rather thick-walled surface-layer, which bears the long, thick-walled, and very brittle rhizoids, often in such great numbers as to form a dense matted investment, as thick as half the diameter of the rhizome. The scales described by Bastit are attached to the projecting corners or ridges. We have not been able to make out the exact distribution of the scales, but they appear to be inserted at considerable intervals along the ridges. Their structure is well described by Bastit (op. cit., pp. $35^{2-5}$, Figs. 44-6). We did not succeed, however, in the midrib of the scales borne by the rhizome proper, in distinguishing his 'bundle' from his 'hypodermic zone.' We find that the midrib consists entirely of elongated thickwalled cells, continuous with those of the hypodermal strand occupying the ridge to which the scale is attached (Figs. I3, I4). Of Bastit's 'cellules allongées en forme de tibia' (p. 354), evidently equivalent to Haberlandt's 'siebröhrenartigen Zellreihen,' we can find no trace in these scales. Possibly Bastit's description refers to scales higher up the stem, showing a transition to the structure of the foliage-leaf.

Below the superficial rhizoid-bearing layer are two or three layers of living cortical parenchyma, thin-walled and polygonal in transverse section. This tissue is interrupted opposite the three ridges by the sclerenchymatous cells of the three hypodermal strands. The extent to which these strands are developed varies very much in different rhizomes, and in different parts of the same rhizome. They are usually quite massive (as in Bastit's Fig. 4I), and their cells have very thick and strongly lignified walls. In other cases their development is much feebler, the walls of their cells being only slightly thicker and darker than those of the ordinary cortical "cells. The cells of the hypodermal strand are distinctly prosenchymatous, with pointed ends. They are living cells sometimes containing starch.

As we pass radially inwards from the thick-walled hypodermal strand, we come to cells of greater diameter, and with 
thinner and less lignified walls. On transverse section these cells usually show no sharp line of separation from those of the hypodermal strand, and form together with it a wedgeshaped mass of tissue gradually narrowing inwards which we propose to call the radial strand. In radial section its inner cells are shorter than those of the hypodermal bundle, and have horizontal end-walls. They often contain starch.

At the inner limit of the cortex comes the layer of strikingly large, radially elongated cells (end., P1. I, Figs. 12, I5; Pl. II, Figs. I6-18) described by Haberlandt and Bastit. Their radial diameter is often nearly twice as great as the tangential. A striking point has been missed by previous observers in the thickening and suberization of their radial and horizontal walls. This layer in fact presents all the characters of a typical root-endodermis. The thickened walls show the distinctive reactions, giving good differential staining with the aniline dyes (e.g. eosin and iodine green, or haematoxylin and safranin), and staining strongly with alcoholic solution of chlorophyll and alkannin.

The endodermis consists of three arcs, each occupying a side of the triangular rhizome. The ends of each are curved slightly inwards, and abut on the inner, larger cells of the radial strand by which the adjacent arcs are separated.

Central Cylinder. This consists of an inner compact mass of tissue with three broad projecting regions, the outer boundaries of which are parallel with the three sides of the rhizome, and three narrower furrows opposite its angles. This central mass consists mainly of very thick-walled elongated living cells, often with oblique end-walls, and containing here and there a little starch. Scattered among these stereids are elements of about the same diameter, but so far as we have seen quite destitute of contents. These are often united, as it appears on transverse section, in bands of two or. three, the cells of each band being separated by extremely delicate cellulose walls, which are really, as Haberlandt has shown, the very oblique end-walls of the cells. The walls abutting on the stereids are also thin and unlignified. For 
these elements, which are exactly like and continuous with those of the central strand of the aerrial stem, and which Haberlandt has, we think, conclusively shown to possess at least a chiefly water-conducting function in the aërial stem, we propose to adopt Potonie's term hydroid, the water-conducting tissue, as a whole, being called hydrom ${ }^{1}$. The above facts relating to the central cylinder have all been described by Haberlandt in $P$. juniperinum (op. cit., pp. 369-70). Bastit fails to distinguish properly between the hydroids and stereids.

In most cases the three-lobed central strand is clothed with a layer of fairly thin-walled living cells. Round each broad projecting lobe this layer abuts immediately on the arc of endodermis, and may fairly be considered as of the nature of a pericycle ${ }^{2}$. Its cells are considerably elongated, with

1 Potonié, Ueber d. Zusammensetzung der Leitbündel bei d. Gefässkryptogamen. Jahrb. d. k. bot. Gartens zu Berlin, ii, I883. As a term in physiological anatomy we think this is preferable to Haberlandt's word hadrom, which also includes associated parenchyma, since it directly expresses the function of the tissue in question rather than the non-essential character of stoutness: Oltmanns (Ueber die Wasserbewegung in der Moospflanze, Strasburg, 1884) objected to Haberlandt's interpretation of this tissue as mainly water-conducting, but on insufficient grounds, which Haberlandt has sufficiently refuted. Coesfeld (Beiträge zur Anatomie und Physiologie der Laubmoose, Bot. Zeit., 1892, p. I53) takes the same view, and states that the occurrence in these cells of oil and proteid, noted as exceptional by previous observers (Goebel, Die Muscineen, Schenk's Handbuch der Botanik, Bd. ii, p. 369 , Breslau, $\mathbf{1 8 8 7}$, and Haberlandt, op. cit.), is general, that small grains of starch also occur in considerable numbers, and that a thin lining of protoplasm can be demonstrated. He suggests that the cells have a water-storing rather than a water-conducting function. He produces however no valid criticism of Haberlandt's experiments. Our own observations, so far as they go, certainly do not indicate the general occurrence of organized contents in these cells, though we have often found in them a good deal of organic substance mainly of proteid nature, and in both $P$. commune and $P$. juniperinum we constantly found a number of cells with dense proteid contents in the upper part of the cylinder of the aërial stem close to the base of the sporogonium. We have not been able to plasmolyse these cells, but we have not investigated the question of the existence of a protoplasmic lining very carefully. It is possible that such may exist, but in any case no nucleus is present. We regard the importance of the water-conducting function of this tissue as established, but no doubt there is a good deal of work yet to be done on the physiological anatomy of these tissues.

2 These pericyclic arcs are not continuous with the pericycle but with the hydromsheath of the aërial stem, owing to the way the transition takes place (see pp. 22 and 23). It should be noted that the layer we have called pericycle in the aërial stem is not, like these layers, stelar conjunctive, but is differentiated from the inner cortex. 
quite thin horizontal or slightly inclined end-walls, and seem always quite destitute of starch. This pericyclic layer may be as much as two or three cells thick, and there may be no very sharp line of separation between it and the stereids of the central strand. It is often interrupted in places, so that genuine stereids come to abut directly on the endodermis. Thin-walled hydroids also are frequently mixed with the pericyclic cells, and may likewise abut upon the endodermis (cf. Haberlandt, op. cit., Taf. XXI, Fig. I8).

Each pericyclic arc follows the broad lobe of the central mass round its angles, and is continuous with the tissue lining the furrows. Haberlandt says nothing about the strands of tissue occupying the three furrows. Bastit calls them 'secteurs péricycliques,' and remarks that they scarcely differ from the tissue immediately external to them (i. e. the inner part of what we have called the radial strands). He also says, however, that the tissue in the furrow 'presents the same characters as the elements of the pericyclic zone of the aërial stem.' Since by 'pericyclic zone of the aërial stem' Bastit refers to Haberlandt's leptom, this last statement, together with the general root-like organization of the rhizome, suggested to us that sieve-tube-like cells might possibly be found in the furrows. This is actually the case. The centre of the bay is occupied by a little group of from six to eight polygonal cells with light yellow walls (lept., Figs. 12, I8, I9). The two innermost of these are commonly larger than the others, and are separated by a particularly thick radial wall (Fig. 17). On transverse section these cells often possess thick granular contents giving proteid reactions, and so far as we have observed never contain starch. In longitudinal section they often show the perfectly typical characters of Haberlandt's 'siebröhrenartigen Zellreihen' (Figs. 15, 16, 16 a). It does not appear that Bastit recognized this fact, notwithstanding his above-quoted statement.

This little group of sieve-tube-like cells (leptoids as we may call them) is surrounded by starchy parenchyma, to which we may apply Troschel's term amylom. To the inside and 
on the flanks is the layer of cells lining the furrow and continuous with the pericycle. This layer is one or two cells thick, and corresponds in character with the pericyclic arcs, except that it is uninterrupted by hydroids, and so far as we have seen always contains starch, which the pericyclic arcs do not. To the outside of the bay the leptom is bounded by the inner narrower portion of the wedge-shaped radial strand, whose cells as already described are rather thin-walled and slightly lignified, somewhat broader than the leptoids and containing starch.

The most striking feature in the arrangement of the fairly complicated tissue-systems of the Polytrichaceous rhizome is undoubtedly its practically complete identity with that obtaining in the root of a vascular plant. We have (I) a surface-layer bearing root-hairs, (2) a cortex bounded internally by a well-differentiated endodermis, (3) a pericycle, though incomplete and often interrupted, (4) a compact central cylinder in which most of the stereom is localized, and exhibiting (5) a definitely tri-radial arrangement of the leptom, the hydromelements being scattered among the stereids in the promontories between the leptom-furrows as well as in the centre of the cylinder. The existence of central tracheae mixed with mechanical elements is a fairly common feature in the roots of Angiosperms, especially among Monocotyledons.

The only points in which the tissue-arrangement differs from the root-type are the incompleteness of the pericycle and endodermis. The former is not only often interrupted by hydroids abutting on the endodermis, but, like the endodermis itself, is not continuous outside the leptom-strands. At these three points the periphery of the cylinder is, in fact, broken by the wedge-shaped masses of thick-walled cells which we have called the radial strands, leading out to the three hypodermal or scale-trace strands. In these last tissues we meet with the stem-nature of the rhizome, as shown by its bearing foliar organs.

The tissues of the central cylinder, i. e. everything within the endodermis and radial strands, may be classified into 
(I) Hydrom, (2) Leptom, (3) Conjunctive tissue, which last we may again divide into $(a)$ stereom (central), $(b)$ unlignified cells without starch (pericyclic arcs), and $(c)$ unlignified cells with starch (amylom, situated between hydrom and leptom). The fundamental resemblance of this (except for the curious fact of the absence of starch from the pericyclic arcs) to the arrangement of tissues in the stele of a vascular plant is sufficiently clear, though the differentiation is distinctly less, especially between the different regions of conjunctive. The entire absence of pits, so far as we have observed, from the tissues of the rhizome is a curious character. It is, however, to be noted that the end-walls of all the comparatively thick-walled cells, except the hypodermal fibres, are much thinner than the side-walls. This is especially the case in the regions of conjunctive $b$ and $c$, and in the inner cells of the radial strand. It is to be presumed that the last two tissues carry on a large part of the carbohydrate conduction. The pericyclic arcs, we imagine, must be concerned in the conduction of nitrogenous compounds, for though its cells are not differentiated as leptoids, the only obvious difference is the absence of bulging at the junction of two cells, and the somewhat greater thickness of their endwalls.

The constancy of starch-distribution in all the sections we have examined, not only in the rhizome but in the aërial stem, is a striking character. Without this indeed, it would be impossible to separate the slightly differentiated tissues to the extent we have been able to do. We have examined plants in different conditions, both when growth was actively proceeding and when it was at a standstill, shoots in a purely vegetative state and others during the development of the sporogonium, but though there is great variation in the amount of starch present, we have found it constantly present in some tissues and constantly absent in others. We have never seen starch in leptoids although Haberlandt says it occurs in them when conduction is slow. We find that starch increases very much, cramming the characteristically 
starchy tissues, in plants kept shut up in a tin box for a fortnight.

The rhizomes of the different species of Polytrichum, according to Bastit, are all built up on fundamentally the same type, and this certainly holds good of the species we have examined. $P$. juniperinum and $P$. formosum (Fig. I9) come very close to $P$. commune, but are smaller and with rather less well differentiated tissues. The hypodermal strands are certainly less massive and with thinner walls, while the cells of the inner part of the radial strands are frequently only to be distinguished from the adjacent cortex by their smaller diameter, especially in $P$. juniperinum. The furrows are on the whole shallower, and hydroids very frequently abut on the endodermis. The outlines of the hydroids are strikingly angular in transverse section, and the angles where the thin, very oblique end-walls are inserted are frequently re-entrant. In $P$. juniperinum the thickness and lignification of the walls of the stereids decrease gradually as the periphery is approached, while the diameter of the cells increases, so that the living cells bordering the endodermis are often quite wide. In $P$. formosum the diameter of the stereids is more constant throughout, but their lignification and the thickness of their walls fall off in the same way. In neither case is it easy to separate a distinct pericycle. Differentiation of the conjunctive has not progressed so far as in $P$. commune.

$P$. piliferum is much smaller and with much feebler tissuedifferentiation. The hypodermal strands are little developed and in places not distinguishable on transverse section. The inner cells of the radial strand are scarcely distinguishable from the adjacent cortex. The furrows are much shallower, sometimes hardly distinguishable. The hydrom-stereom strand is small and often irregular in outline. The stereids are fairly thick-walled but very variable in diameter, the peripheral ones being quite wide. The hydroids are very few in number, of the same type as in $P$. juniperinum and formosum. 
It is a striking fact that all these species, however badly differentiated in other respects, have the endodermis well marked.

The transition of the rhizome to the aërial stem takes place very slowly, and begins very low down, so that the typical anatomical characters of the rhizome are lost long before there is any alteration in external features. For this reason it is necessary to dig up the plants very carefully and obtain a considerable length of rhizome in order to get sections showing the typical features. A section of $P$. juniperinum cut three-quarters of an inch below the beginning of the strictly subterranean rhizoid-bearing portion will often still show transitional phenomena.

The anatomical features of the transition have in the main been correctly described by Bastit (op. cit., pp. 356-360, Figs. 47-50), though his curious terminology and apparent want of appreciation of the real nature of the tissues involved considerably detract from the value of his account.

The first thing that happens is the lateral extension of the hypodermal strands. These eventually meet and become continuous with the sclerenchymatous outer cortical zone of the aërial stem, as Haberlandt and Bastit have stated. This zone is already continuous, occupying the whole of the cortex down to the endodermis, before the stele loses its typical rhizome character. Meanwhile the hydroids have increased in size and number, and the larger ones tend to concentrate in the centre of the stele while the stereids correspondingly become fewer. At this stage the leptoid groups are extremely obvious, one or two of the elements often becoming very large, and their walls, which are pale straw-colour, standing out very clearly from the dark chestnutbrown walls of the surrounding tissue. The endodermis begins to lose its characters, and, together with the cells of the inner part of the radial strand, forms the foundation of the inner cortex of the aerrial stem. The sides of the stem flatten so that it becomes a three-sided prism. The stereids of the stele decrease to very few so that the files of hydroids 
come into lateral contact, separated by thick walls. The central hydrom-stereom mass is now surrounded by a complete investment, one or two cells thick, of starch-containing parenchyma with dark brown walls, continuous below with the pericycle and the starchy tissue internal to the leptom, and forming the characteristic starchy hydrom-sheath of the aërial stem. The furrows become shallower and gradually the hydrom-strand, which has by now lost the whole of its stereom, becomes cylindrical. At this level the files of large hydroids which occupy the centre of the stele are surrounded by scattered smaller ones, continuous with the small hydroids found in the pericycle of the rhizome, and these are mixed with moderately thick-walled starch-containing cells abutting on the dark brown hydrom-sheath. Higher up, these last cells are lost or absorbed in the hydrom-sheath, while the small hydroids increase in number and form the peripheral thinwalled hydrom-mantle of the stele of the aërial stem. The three leptom-strands are now completely outside the circumference of the cylindrical hydrom, from which they are separated by the fairly broad starchy sheath already described (Fig. 22). Externally they are bounded by smaller cells, which are often, however, not clearly distinguishable from those of the inner cortex. At this time each leptom-strand consists of two or three leptoids only, and it is only at a considerable higher level that the number is multiplied and lateral extension of each group begins, finally resulting in their fusion to form a complete peripheral leptom-mantle. Bastit figures this as taking place much lower down, before the peripheral ring of cortical stereom is complete (op. cit., Figs. 48, 49, p. 358), and he altogether misses the stage at which the still isodiametric leptom-strands are entirely outside the cylindrical hydrom.

Side by side with the lateral extension of the leptoids to form a complete leptom-mantle, the small peripheral hydroids increase in number and eventually form a complete wide zone round the larger central ones. At the same time obvious leaf-traces begin to appear in the cortex, in direct relation 
to the appearance as we pass upwards of the two mantles of the stele. Thus we pass to the typical structure of the leafy aërial stem.

\section{AËrial leafy Stem.}

The histology of this has been described by Haberlandt and Bastit in $P$. juniperinum, and by Coesfeld in $P$. commune. To the former we owe the first good detailed account of its structure. Haberlandt finds the peripheral hydrom-mantle surrounded by a layer of leptom three or four cells thick, composed of $(a)$ wider sieve-tube-like cells, and $(b)$ narrower cells with oblique end-walls corresponding with 'cambiform' (elongated phloem-parenchyma) in Angiosperms. The only other differentiation in the leptom is the suberization of the walls of the inner layer or two of cells. These suberized cells do not, however, according to Haberlandt, differ in form or contents from the outer unsuberized layers (cf. his Fig. II, Taf. XXIII). We find, on the contrary, in agreement with Strasburger ${ }^{1}$, Goebel ${ }^{2}$, and Coesfeld ${ }^{3}$, that the peripheral hydrom-mantle is immediately surrounded by one or two layers of cells with dark brown suberized walls and starchy contents, in fact an amylom-layer-the walls of which, according to Coesfeld (op. cit.), are folded like those of an endodermis-our hydrom-sheath, while immediately outside this comes a layer interrupted here and there by starchy cells, and rarely more than one cell thick, of typical sieve-tube-like cells or leptoids with no starch and light walls-the leptom-mantle. This is strangely neglected by the recent writers on the subject, Coesfeld (op. cit.) and Strasburger (Bot. Practicum, 2nd ed., 1897), although it is extremely easy to distinguish in $P$. commune on staining with iodine. External to the leptom-mantle comes a layer of cells shading into the inner cortex, but of rather less diameter, with rather thinner, nearly colourless walls, and particularly abundant starchy contents.

1 Botanisches Practicum, Ist ed., 1884, p. 304.

2 Muscineen, in Schenk's Handbuch, ii, p. 369.

3 Beiträge zur Anat. u. Phys. der Laubmoose, Bot. Zeit., 1892. 
This layer, barely differentiated from the inner cortex, we propose to separate as a rudimentary pericycle. It is not, however, continuous with, and clearly has a different origin from what we have called the pericyclic arcs of the rhizome. It is considerably interrupted by the incoming leaf-traces.

Bastit calls the hydrom 'moelle,' the hydrom-sheath 'péricycle intérieur,' and the leptom (as limited by us) 'péricycle extérieur.' He does not recognize the existence of sieve-tubelike cells at all, but mentions the fact that the 'péricycle intérieur' has starchy contents. The three terminologies arranged in parallel columns may be of assistance to the reader.

\begin{tabular}{|c|c|c|}
\hline & Moelle intérieure & Central thick-walled \\
\hline Hadrom & Moelle extérieure & $\begin{array}{l}\text { hydrom-cylinder. } \\
\text { Peripheral thin-walled } \\
\text { hydrom-mantle. }\end{array}$ \\
\hline Leptom & $\left\{\begin{array}{l}\text { Péricycle intérieur } \\
\text { Péricycle extérieur }\end{array}\right.$ & $\begin{array}{l}\text { Hydrom-sheath. } \\
\text { Leptom. }\end{array}$ \\
\hline Rinde & Écorce & $\left\{\begin{array}{l}\text { Rudimentary pericycle, } \\
\text { Cortex. }\end{array}\right.$ \\
\hline
\end{tabular}

Our Figs. 20 and $2 \bar{I}$ will enable the reader to distinguish the different tissue-systems.

The constitution of the stele cannot be properly understood without reference to the leaf-traces, to which we now turn.

The general features of the bundle of the leaf of Polytrichaceae have been well described by Haberlandt in Atrichum undulatum (pp. 402-4) and by Bastit in $P$. juniperinum. The former describes the living cells of the bundle as 'Leitparenchym,' while the latter describes them as 'cellules en forme de tibia.' We are able to confirm Bastit's observation. In a transverse section of the leaf of $P$. commune, the living cells of the bundle form three rows parallel to the surface of the leaf. The cells of the middle row have the largest transverse section, are lined with a thin layer of protoplasm and contain no starch, while the top and bottom rows consist of slightly smaller cells (amylom) containing starch. At the corners of the cells between the rows are the two series of 
very narrow hydroids, square in section, each abutting on four or usually five living cells (cf. Bastit, Fig. 2, Pl. XIII).

In longitudinal section the middle row of living cells is clearly seen to consist of leptoids, many though not all of the cells having the characteristic bulging ends and very thin transverse walls (Bastit, Pl. XIII, Fig. 4 in P. juniperinum).

Though many of the facts relating to the passage of the leaf-traces through the cortex have been described by Haberlandt (pp. 404-5) and Bastit, we have thought it well to describe the histological features fully, as their accounts are by no means complete, and a full understanding of the relations are necessary to an appreciation of the morphological nature of the different tissues of the conducting system.

On entering the cortex the leaf-bundle at first maintains its general form, though the characteristic shape of the leptoids in longitudinal section does not appear to be maintained during their passage through the cortex, and the inner layer of accompanying starchy cells frequently becomes somewhat irregular.

The outer and inner rows of starchy parenchyma have dark brown walls, while the light yellow walls of the leptoids stand out clearly against the thick dark brown walls of the outer cortex.

No marked change of form is noticeable on the transverse section till the VIIth trace (Fig. 20) counting inwards is reached. This trace has arrived at the somewhat smallercelled and thinner-walled abundantly starchy layer forming the extreme internal layer of the cortex, which we propose to call a rudimentary pericycle (see above, rud.per., Fig. 20).

As the inner layer of living cells of the trace reaches this, its cells change their character, becoming larger and lighter walled, in fact assuming the characters of the pericycle itself, At the same time the whole trace lessens its tangential length, becoming isodiametric instead of band-shaped, increasing the number of its leptoids from a single band of about six to nine or ten in a group, while the hydroids begin to lose their regular arrangement (Fig. 20, VIII and IX). The trace now 
pushes through the stelar leptom-mantle and its inner (pericyclic) cells just mentioned join the dark-walled starchy hydrom-sheath. At the same time the hydroids also rather suddenly increase in number, collecting together in a strand roughly circular in section (XI and XII), while the leptoids appear to go off right and left in two groups to form part of the stelar leptom-mantle (X and XI). The outer layer of dark brown-walled starchy parenchyma belonging to the trace is still seen immediately external to and on each side of the hydroid-strand (XII). The latter now pushes forwards and joins the peripheral thin-walled hydrom-mantle with which its elements are identical in every respect, the starchy sheath of the leaf-trace joining the starchy hydrom-sheath of the stele in the same way (traces XIII and XIV) ${ }^{1}$.

The most important fact to notice in this series of phenomena is the formation, as it were, of the whole of the stemstele with the exception of the central thick-walled hydromcylinder and the rudimentary pericycle, from the bases of leaf-traces. All the elements of the stelar leptom at a given level can be accounted for as belonging to about six leaftraces (in Fig. 20 those numbered $\mathrm{X}$ to $\mathrm{XV}$ inclusive) completing in the phyllotactic spiral about two circuits of the stele. The same may be said of the elements of the hydromsheath and of the thin-walled peripheral hydrom-mantle, though here, owing to the complete merging of the incoming

1 Coesfeld (op. cit., p. I64) states that the large cells of the trace (our leptoids) enter the peripheral ring of the hydrom-cylinder together with the hydroids. We do not believe that this is the case. The cylindrical strand of thin-walled elements surrounded by a starchy sheath and representing the base of a trace (XI and XII) certainly differs from the row of isolated hydroids of the band-shaped upper portion of the trace; the elements are much more numerous, are wider, and often have disorganized contents. But they always differ from the leptoids of the upper part of the trace and of the leptom-mantle in having no nucleus. Together with the cells of the peripheral thin-walled mantle of the central part of the stele, with which they are continuous and identical in character, they represent, according to our theory (see third section), the last part of the hydrom-system to be evolved, the final connexion between the detached leaf-trace and the hydrom of the primitive stele. Their differentiation appears to be more rudimentary than that of the other hydroids. It may be that they help to conduct formed material under some circumstances, but they clearly do not belong to the regular leptom-system. 
hydroid strands in the stelar mantle, the elements actually belonging to the different traces can no longer be distinguished. We have in fact a stele entirely composed (with the above-noted exceptions) of leaf-traces, a state of things which corresponds to that obtaining when all the bundles in the stem of a Phanerogam are 'common bundles.' The implications of this will be discussed in the third section of these 'Notes.' Coesfeld (op. cit., pp. 156-8) objects to the separation of the central thick-walled strand from the outer thin-walled mantle. But the sharp line of separation between the two is obvious enough as an anatomical fact in $P$.commune and often in $P$.juniperinum, and in all the species a difference can be made out between the peripheral and the central tissue. It is perfectly true that 'the whole tissue of the central strand is homogeneously laid down behind the growing point,' but that is only what one always finds when two tissues of similar form are developed in contact. 'Developmental' facts of that kind can have no bearing on morphological conclusions. Variability in thickening of the walls of the peripheral zone, both in different species and also in different stems belonging to the same species, certainly exists, and sometimes the mantle shades gradually into the central strand, but this assimilation of the neighbouring cells of regions primitively distinct is again a familiar enough fact throughout plant-histology, and cannot we think be set against the kind of general evidence we have adduced in the third section of these Notes.

The aërial stems of $P$.juniperinum, formosum and piliferum, like their rhizomes, resemble that of $P$. commune in all fundamental respects, though their tissues are rather less welldifferentiated, on the whole thinner-walled, and consequently more difficult to separate. The diameter of the hydroids in the central thick-walled cylinder of $P$. juniperinum is less than in $P$. commune. The peripheral hydroid mantle is thicker-walled, the distinction between the two being less sharp. The other layers of the stele are well marked, the pericycle being distinctly thinner-walled and more sharply 
separated from the cortex than in the stouter species, while the cortex itself is distinctly thinner and the number of leaftraces present at a given level decidedly less, only seven to ten being found outside the hydroid mantle (cf. Bastit, Fig. $3 \circ$ p. 269). There is but a single row of hydroids in the leafbundle between the leptoids and the lower (outer) row of starchy 'Leitparenchym,' which last when it enters the cortex has, as Haberlandt states, much lighter walls than in P.commune. The inner row of 'Leitparenchym' loses itself in the cortex. The changes in form of the trace as it passes into the cylinder are quite similar to those in $P$. commune.

$P$. formosum has very much thinner-walled tissues than either of the two preceding species. Its central thick-walled hydrom-strand has a considerably smaller diameter, but its elements are very like those of $P$. commune. The peripheral hydrom-mantle is very thin-walled and relatively very broad, and the hydrom-sheath is well differentiated. The tissues outside this, however, including all but the surface-layer of the cortex, are quite thin-walled, and the leaf-traces are not at first sight easy to distinguish. Their behaviour seems, however, to agree in essentials with that obtaining in the other species. There are not more than ten present outside the hydrom in any given section.

In $P$.piliferum the central cylindrical strand is large relatively to the diameter of the peripheral mantle, which is not very well differentiated from it. The hydroids are rather narrow. The hydroid-sheath is large-celled and thick-walled -very well-marked. The leptom-mantle is difficult to distinguish in the transverse section. The leptoids are comparatively few in number, their walls do not differ from those of the adjacent tissues, and their cells often contain granules which before treatment with iodine much resemble the starch of the other tissues. The leptoids of the mantle are seen, however, on longitudinal section to possess typical characters, and we have not found starch in them. On the other hand, the corresponding cells of the leaf-bundle and trace often do contain starch and show no differentiation from ordinary 
'Leitparenchym.' The cortex is narrow and there are only about six or seven traces present outside the hydroid cylinder. These, except for the fact above noted, are of quite the same type as in the other species.

\section{The Nature and Origin of the Conducting Tissues IN MOSsES.}

Unger ${ }^{1}$ was the first to compare the 'central strand 'found in the great majority of moss-stems with the vascular strand of a higher plant, while he and Lorent $z^{2}$ discovered and described the leaf-bundle and the leaf-trace which sometimes continues the leaf-bundle downwards into the stem. Lorentz also discovered the remarkable fact that in some cases the leaf-traces end blindly in the cortex of the stem ("falsche Blattspuren'), while in others they join on to the central cylinder, as in the Vascular Plants ('echte Blattspuren'). Haberlandt, in his 'Beiträge,' advanced the whole subject enormously by giving definiteness to the previously vague attribution of the function of 'conduction' to these tissues, showing by experiment ${ }^{3}$ that the central strand of most moss-stems is a water-conducting channel, a rudimentary 'Hadrom,' and that in Polytrichaceae there are in addition tissues which function as conductors of plastic food-material, both carbohydrate and nitrogenous. In the second section of the present 'Notes' we have shown that in both rhizome and aërial stem there is a layer of starchy parenchyma between hydrom and leptom, just as in all vascular plants (Russow's 'Xylem-scheide' in Ferns), and also indications of a rudimentary pericycle outside the leptom of the aërial stem. In fact there are parallels among the Polytrichaceae for all the main categories of the stelar tissue of the true vascular plants with the exception of primary phloem-fibres, which are always rare.

\footnotetext{
1 Beiträge zur Physiologie der Pflanzen : vii. Ueber den anatomischen Bau des Moosstammes. Sitzungsb. d. Wien. Akad., I 86r.

2 Grundlinien.

3 Ber. d. Deutsch. bot. Ges., 1883.
} 
With regard to the evolution of this complicated system of conducting tissues, we can follow in the completest way the different stages of its differentiation.

The very earliest stages are not yet known among the Mosses themselves, but we find one type in the leaves of the leafy Liverwort Diplophyllum, and the other in the midrib of the thallus of the plant from Malahide at present known as Pallavicinia hibernica, var. $\beta$, Wilsoniana.

The first demand in a leafy plant vegetating in a damp atmosphere, and capable of absorbing water more or less over its whole surface, is probably for easy conduction of formed food-substances away from the leaves, rather than for the rapid supply of water to the leaves. The former is probably the function of the living elongated cells forming the midrib of the Diplophyllum leaf. The strands of prosenchymatous lignified cells in the midribs of the thallus in Pallavicinia, Symphyogyna, and Hymenophyton on the other hand are no doubt water-conducting, as we have shown in the case of $P$. Lyellii. Of these, the strands of $P$. hibernica $\beta$, Wilsoniana are certainly the least differentiated, and in all probability the most primitive. The cells of the strand are more elongated than the cortical cells, but their walls, though slightly lignified, are scarcely thicker than those of the cortex. They are not entirely destitute of contents, though we have not been able to make out that any of them possess a nucleus. Taking all the facts into consideration, in the absence of experiment it is probable that they function as a waterconducting channel. From this type we pass to the very long and narrow, thick-walled, lignified, and richly pitted elements typical of the central strand in the three genera named. These may be regarded as comparatively highly differentiated hydroids.

In the majority of the Mosses we have a similar stage of development in the central strand of the stem, except that here the hydroids are thin-walled and nearly always without pits. The leaves possess in their midribs elongated living cells, no doubt for the conduction of formed organic sub- 
stances into the stem, and frequently hydroids associated with these. The leaf-bundles are not usually continued into the stem, the conduction in the stem itself of the formed substances coming from the leaves being carried on no doubt by the longitudinally elongated cortical cells. With regard to the conduction of water, it seems to take place, in some cases at least, across the cortex from the central strand to the bases of the leaves. But no doubt nearly all Mosses take up water through their leaves on occasion, while the aquatic, semiaquatic, and xerophilous types, as Haberlandt has shown, habitually do so, and possess no conducting system at all or one which is very feebly developed. It is probably owing to the retention of this primitive habit in many terrestrial Mosses that a more efficient water-conducting system is dispensed with. A certain number of terrestrial forms, however, have evidently felt the need of such a system. In Mnium, Bryum, and some species of Splachnum, the hydroids of the leaf-bundles are prolonged into the stem, but curiously enough, instead of crossing the cortex to join the central cylinder, they bend down and pursue a vertical course near the edge of the cortex, parallel with the long axis of the stem. These leaf-traces or their lower ends have their surface increased in various ways, i. e. they may be band-shaped or star-shaped in cross-section so as to present a larger surface to the cortical cells through which their water must come. In Funaria hygrometrica the leaf-traces take an obliquely radial course through the cortex, and approach the central cylinder, but usually just stop short of it, though in some cases they actually join it. Finally, in some species of Splachnum, in Voitia nivalis, and throughout the Polytrichaceae, the traces regularly join the cylinder.

The first thing that strikes one in considering this series of facts is the entire separateness in evolution between the primitive moss-stele and the leaf-bundles. Not only do they appear quite independently in the lowest types, but in the case of the (no doubt phylogenetically subsequent) continuation of the leaf-bundle back into the stem as a leaf-trace, the latter 
is often quite unconnected spatially, though it clearly has a physiological connexion with the stele. It is only as a second thought, so to speak, that the establishment of a direct spatial connexion with the hydrom of the cylinder occurs to the trace, as being the simplest and most effective means of establishing a water-channel between the absorbing part of the stem and the leaf. In none of the higher plants, so far as we know, is anything similar found. However simple or complex the stele may be, the leaf-traces are always in direct connexion with it from the outset. This being so, it is difficult to believe that the stem-stele and leaf-bundle of the Mosses were evolved as parts of a single conducting system designed for a single purpose. The explanation that suggests itself to us is that the stem-stele originated in the first instance in order to supply the growing apex (cf. Strasburger, Practicum, xxi Pensum), the sexual organs, and particularly the developing sporogonium, with water; while the leaf-bundles originated quite independently, at first probably in the form of a median strand of 'Leitparenchym' (as in the Liverwort Diplophyllum and many Mosses), to conduct the products of assimilation away from the leaf, hydroids being afterwards associated to facilitate the passage of water to, and possibly from, the leaf, as alternately the transpiring and absorbing organ. In those forms which adopted a purely terrestrial habit, rooted in soil and expanding their leafy shoots in air which was often relatively dry, the current of water up the stem became more constant and the leaves became more regularly and to a greater extent transpiring organs. A demand for easier conduction from stem to leaf was felt and was met by the continuation of the water-conducting part of the leaf-bundle into the stem, where it was expanded in various ways (Mnium, Bryum, Splachnum) in order to present a larger surface to the cortical tissue, so that the leaf-bundle could indirectly tap the water in the central strand to greater advantage.

The habitats and habits of the plants belonging to these genera completely correspond with the existence of such 
a demand, and Haberlandt has shown that conduction of water up the central strand and its passage thence into the leaf-traces and leaf-bundles, to meet the losses caused by transpiration, is a regular occurrence in Mnium undulatum. Finally, the more direct and efficient method of the establishment of continuity between the hydrom of the stem-cylinder and the hydrom of the leaf-bundle has been adopted in the case of other species of Splachnum, and in all the Polytrichaceae. In the last-named family we have, for the first time, the 'Leitparenchym' (some of the cells of which have now assumed the characters of a distinct leptom) also continued down, side by side with the hydrom, from the leaf-bundle into the leaf-trace, and so into the leptom-mantle and starchy hydrom-sheath of the stem-cylinder.

We think that the present theory is distinctly borne out in rather a striking way by the facts with regard to the constitution of the Polytrichaceous stem-cylinder set out at the end of the last section. The central thick-walled hydromcylinder is entirely independent of the leaf-traces and passes up to the top of the stem, where in the case of a sporogoniumbearing shoot it changes its characters, becoming thin-walled and often mixed with cells having dense proteid contents and envelopes the base of the sporogonium. This, in our view, is the primitive hydrom-cylinder of the stem of the gametophyte. The thin-walled peripheral hydrom-mantle, on the other hand, composed, as Haberlandt has pointed out, of elements identical with the hydroids of the leaf-traces, is as a matter of fact entirely formed from the bases of the hydromstrands of these traces, and decreases in thickness upwards, ceasing to exist above the level of exit of the last of the traces; while below it rapidly diminishes after the lowest of the traces has joined the stele, and is represented in the rhizome by a very few elements in the region of the 'pericycle.' The peripheral hydrom-mantle is then a new formation, only arising with the attachment of the bases of the leaf-traces to the stem-cylinder.

Nearly the same may be said of the leptom-mantle, which 
in the leafy stem is clearly enough composed of the bases of the leptom-strands of the leaf-traces. Traced upwards, however, after the passing out of the last of the leaf-traces, it is continued upwards together with the altered cells of the hydrom-sheath, which no longer contain starch: consisting of a layer of thin-walled elongated cells, often with dense proteid contents, but in which no typical leptoids can be detected, it overlaps the central hydrom and comes into contact at a higher level with the base of the sporogonium, to which no doubt it supplies plastic substances for the formation of the young spore-capsule. Below the lowest leaf-trace the leptoids, as we have seen, decrease in number very considerably, and the remaining ones are concentrated in three strands which run down into the furrows of the hydrom-stereom cylinder of the rhizome.

According to this view, the highly developed Polytrichaceous stele is in the aërial stem essentially double in nature and phylogenetic origin, consisting (I) of a central primitive hydrom-cylinder, originally developed and still serving to supply the apical bud, sexual organs, and sporogonium with water, and (2) of a double peripheral mantle of hydrom and leptom separated by a starchy hydrom-sheath (amylom), all three layers composed of the joined bases of leaf-traces and designed between them to conduct water to, and formed material from, the leaves.

The bearing of these considerations on the problem of the nature and origin of the primitive stele among the Pteridophytes, as we find it for instance among the Sphenophyllineae and Lycopodineae, is a very interesting question which we cannot here discuss at length. We can only suggest the possibility of two alternative explanations of such a stele. Assuming first for simplicity's sake the truth of the Bowerian theory, we may on the one hand suppose the primitive Pteridophyte descended from a form bearing a terminal fruitbody, rather of the nature of the sporogonium of an Anthoceros, and with a primitive hydrom-stele comparable with that of the Mosses, but supplying this fruit-body directly (since it 
is developed in the sporophyte) instead of merely leading up to the base of the sporogonium. The lineal descendant of such a primitive hydrom-stele would then perhaps be seen in the central metaxylem of, for instance, Sphenophyllum, Cheirostrobus, the Lepidodendra with solid steles, the monostelic Selaginellas, and (modified in various ways) in Psilotum, Lycopodium, \&c. Added to this would be the bases of the leaf-traces, represented by the peripheral protoxylem-strands (separate, or as in Lepidodendron laterally confluent) and only evolved after the primitive sporophyte had thrown out leaves requiring a vascular supply connected with the main channel of the stem. The fact that they appear before the central xylem in the development of the individual stem would be merely in relation to the need for the early establishment of conducting channels to the leaves, a need which is universal in leafy vascular plants.

On the other hand we might suppose that the formation of leaf-structures requiring a vascular supply preceded the formation of a regular stele supplying the fruit-body, in which case the leaf-traces, represented in the first place by the protoxylem-strands, would be phylogenetically prior, and the central metaxylem would be a later formation, developed in the larger forms to furnish additional conducting channels to supplement the protoxylems in supplying the needs of the higher foliage-leaves and the sporophylls.

And if, setting aside the antithetic theory, we imagine the evolution of the sporophyte from the alternate generation of a homogenetic thalloid form, the elements of the problem are not essentially changed. It is still, as it appears to us, a question of the priority in evolution of leaf-structures on the one hand, or of a differentiated conducting strand on the other. In the latter case the metaxylem of the protostelic Pteridophyte may represent a primitive water-conducting strand in the centre of a thallus, such as we find in Pallavicinia ; in the former, merely a later-formed supplement to the connected system of leaf-traces. 


\title{
Conducting Tissue-System in Bryophyta.
}

\section{EXPLANATION OF FIGURES IN PLATES I AND II.}

\author{
Illustrating Mr. Tansley's and Miss Chick's paper on the Conducting \\ Tissue-System in Bryophyta.
}

\section{PLATE I.}

Section I. The Conducting Strands of Liverworts.

Fig. I. Transverse section of midrib of thallus of Pallavicinia hibernica (Hooker), S. F. Gray, $\beta$. Wilsoniana, Carrington, from Malahide, co. Dublin, showing two lateral strands of thin-walled but lignified, probably water-conducting cells. $\times 4^{8}$.

Fig. 2. Part of longitudinal section of the same, passing through one of the strands; showing elongated, slightly prosenchymatous shape, and scanty disorganized contents of the strand-cells. At $a$, very thin cross-wall in a long strandcell. The lignification extends to parts of the walls of the neighbouring cortical cells. $\times 50$.

Fig. 3. Transverse section of midrib of thallus of Pallavicinia Lyellii (Hooker), S. F. Gray, showing central strand of narrow thick-walled hydroids, and a few rhizoids on ventral surface. $\times$ I IO.

Fig. 4. Parts of hydroids of Pallavicinia decipiens, Mitten, showing the often irregularly scattered pits. These are oval or elongated in surface view, with their long axes perpendicular to the long axis of the cell, or more often slightly inclined, so that the pits are arranged on imaginary spirals running round the cell. In section they are seen to be normal deep simple pits. Where a hydroid abuts on a cortical cell (left-hand hydroid and left-hand wall of right-hand group) the thin wall of the latter is quite unpitted, while the wall of the hydroid may be richly pitted. $\frac{1}{12}$ " oil immersion. $\times 500$.

Fig. 5. Transverse section of midrib of thallus of Symphyogyna sinuata (Sw.), Mont. et N., showing rhizoids on ventral surface of thallus and weak central hydromstrand. $\times$ Ioo.

Fig. 6. Transverse section of midrib of thallus of $S$. Brasiliensis (N. ab. E.), Mont., showing absence of rhizoids and bulky strand with cells of larger diameter at the periphery. $\times 100$.

Fig. 7. Diagram of transverse section of frond-stalk of $S$. rhizobola, showing relation of diameter of bulky strand to that of whole stalk.

Fig. 8. Transverse section of rhizome of the same, showing rhizoids and relatively weaker strand. $\times$ Ioo.

Fig. 9. Transverse section of comparatively weak rhizome-strand of Hymenophyton Phyllanthus (Hooker), Dum. $\times 145$.

Fig. 10. Transverse section of bulky band-shaped strand of frond-stalk of $H$. fabellatum (Hooker), Dum. $\times$ Ioo.

Fig. II. Upper part of midrib of leaf of Diplophyllum albicans (L.), Dum., in surface view, showing elongated cells of rib with sparsely and very irregularly pitted walls and much fewer chloroplasts than the square cells forming the rest of the leaf. $\times 200$. 
Section II. The Histology of the Rhizome and Aërial Stem in Polytrichum.

Fig. I 2. Part of transverse section of the rhizome of $P$. commune. Central three-lobed hydrom-stereom cylinder: hyd., hydroids ; ster., stereids ; per., pericyclic arc; end., endodermal arcs. In the furrows the groups of lept., leptoids, and amyl., starchy tissue. Outside these, i. r. s., the inner larger cells of the radial strands; hyp. st., the hypodermal strands; cor., cortex; rh., rhizoids. $\times \mathrm{I} 45$.

Fig. I3. Transverse section of hypodermal strand of same, immediately above point of insertion of a scale; midrib of latter is seen to consist of thick-walled tissue like that of hypodermal strand. $\times 145$.

Fig. I4. Radial longitudinal section of same, showing insertion of scale and hypodermal (scale-trace) strand giving off branch which becomes midrib of scale: c.c., central cylinder.

Fig. I5. Part of radial longitudinal section of same, passing through lobe of cylinder; references as in Fig. I $2 . \times 245$.

\section{PLATE II.}

Fig. I6. Part of longitudinal section of same, passing through edge of lobe and furrow of cylinder; references as in Fig. I2. $\times$ I 45.

Fig. I6 a Part of three leptoids from Fig. I6. $\times 570$.

Fig. 17 . Transverse section of a leptom-strand of rhizome of same : lept., leptoids ; amyl., amylom; i.r. s., inner cells of radial strand. $\times 3^{8} 5$.

Fig. I8. Transverse section of central cylinder of another rhizome of same, showing gradual transition from stereom to pericycle. References as before. $\times 145$.

Fig. I 9. Part of transverse section of rhizome of $P$. formosum, showing shallowness of furrows, absence of well-marked pericycle, angularity of hydroids, and hydroids abutting on endodermis; references as in Fig. 12.

Fig. 20. Transverse section of central tissues of aërial leafy stem of $P$. commune, showing entrance of leaf-traces into the mantles of the central cylinder: cor., cortex; rud. per., rudimentary pericycle; hyd., hydroids of leaf-traces; hyd.e., peripheral hydrom-mantle; hyd. $i$., thick-walled central hydroids of cylinder; lept., leptoids of leaf-traces and mantle; amyl. (amylom), starchy conducting parenchyma of leaf-traces; hyd. sh., hydrom-sheath. The leaf-traces are numbered from without inwards in Roman figures.

Fig. 21. Part of radial longitudinal section of leafy aërial stem of $P$. commune: cor., cortex ; rud. per., rudimentary pericycle ; lept., typical leptoids ; hyd. sh., hydrom-sheath packed with starch; hyd.e., peripheral thin-walled hydrom-mantle; hyd. $i$., central thick-walled hydrom. $\times 200$.

Fig. 22. Transverse section of transitional region of $P$. commune: lept., showing the three isodiametric leptom-groups; hyd., hydrom-strand which has now lost all stereids; hyd. sh., hydrom-sheath; $x$., small cells with starch bounding leptomgroups. $\times 230$. 

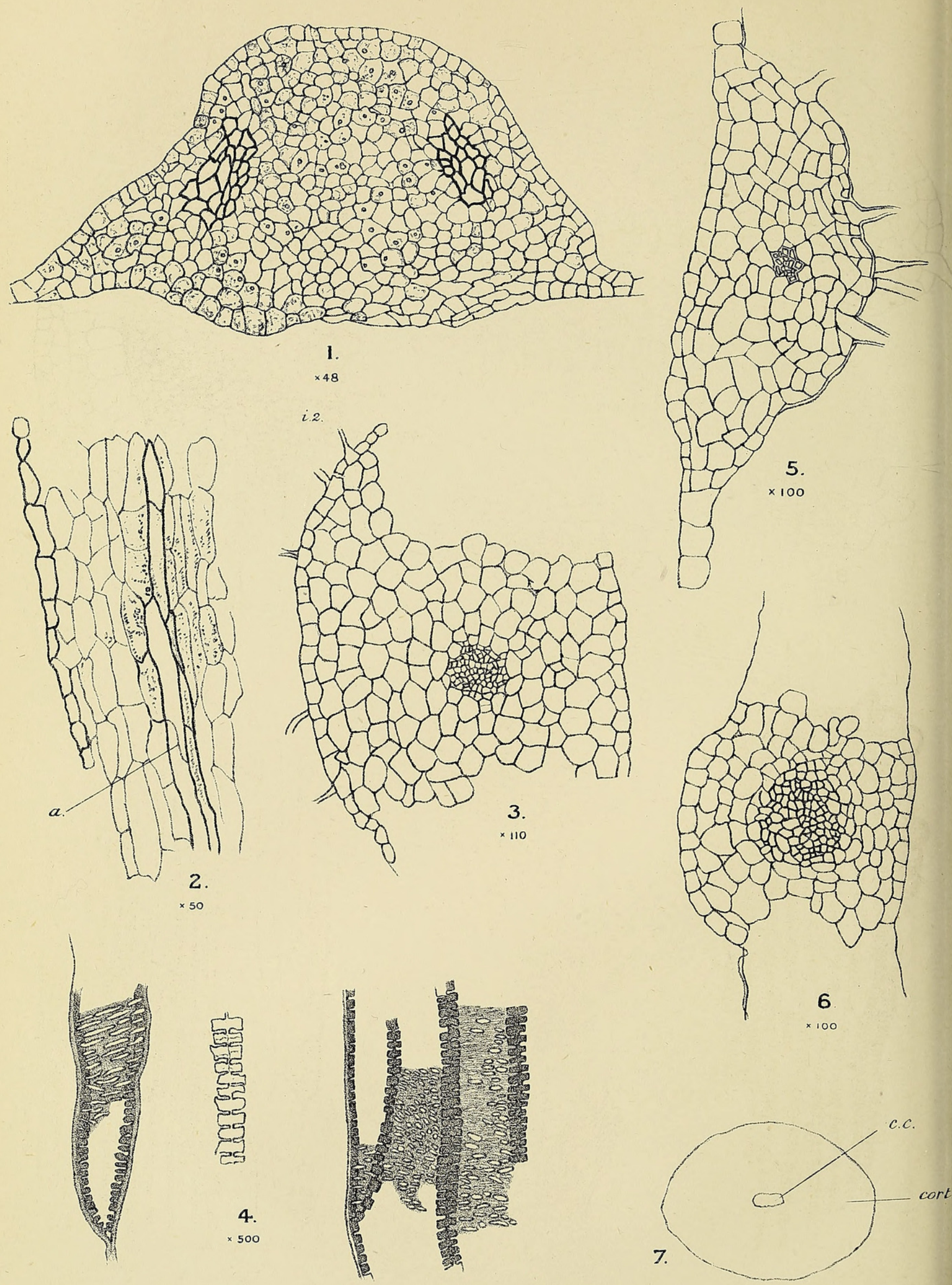

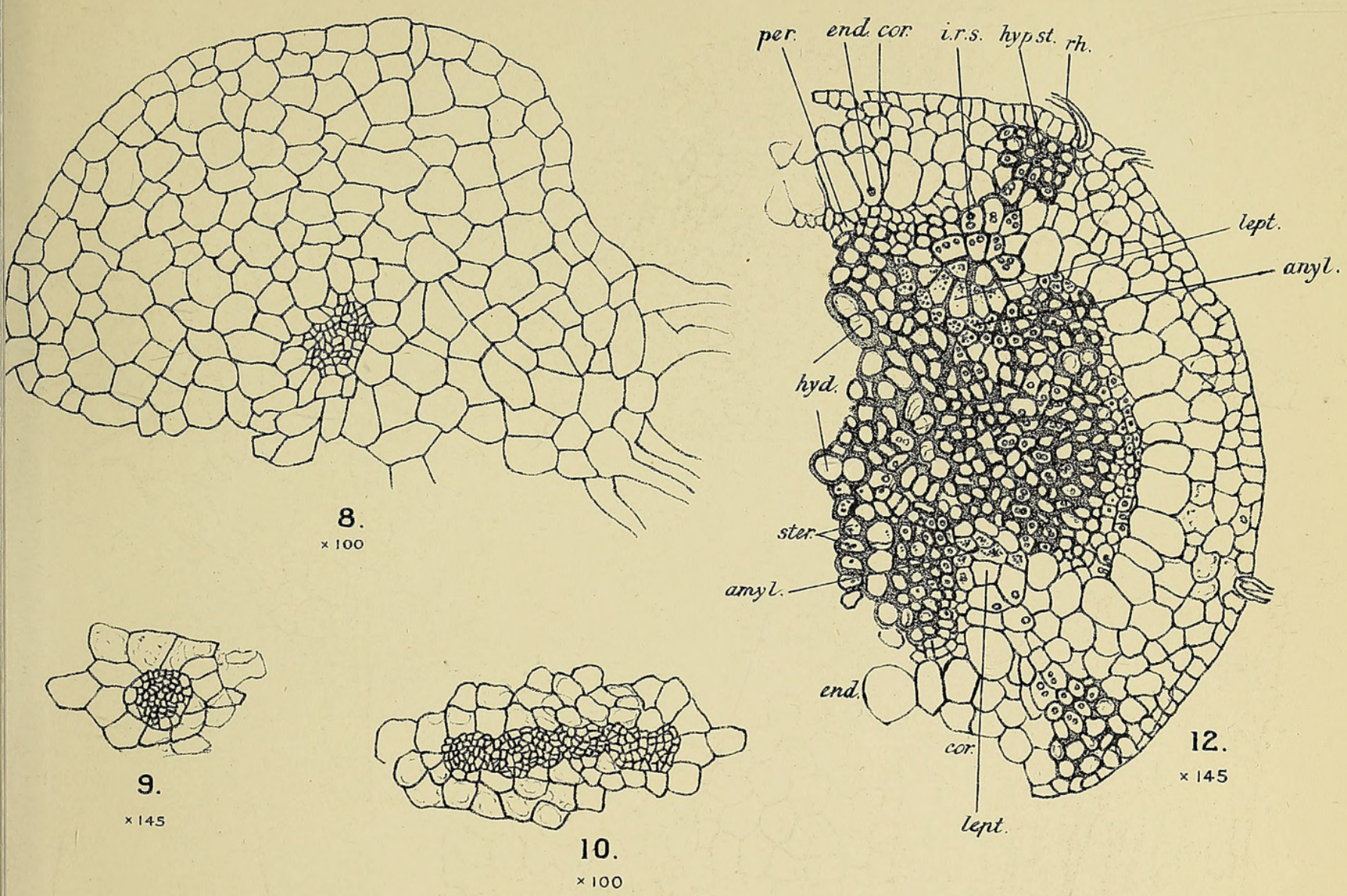

9.

$\times 145$

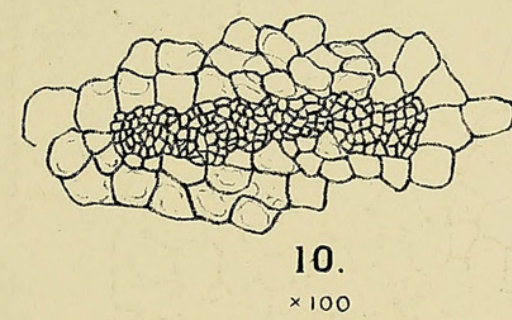

$\times 100$

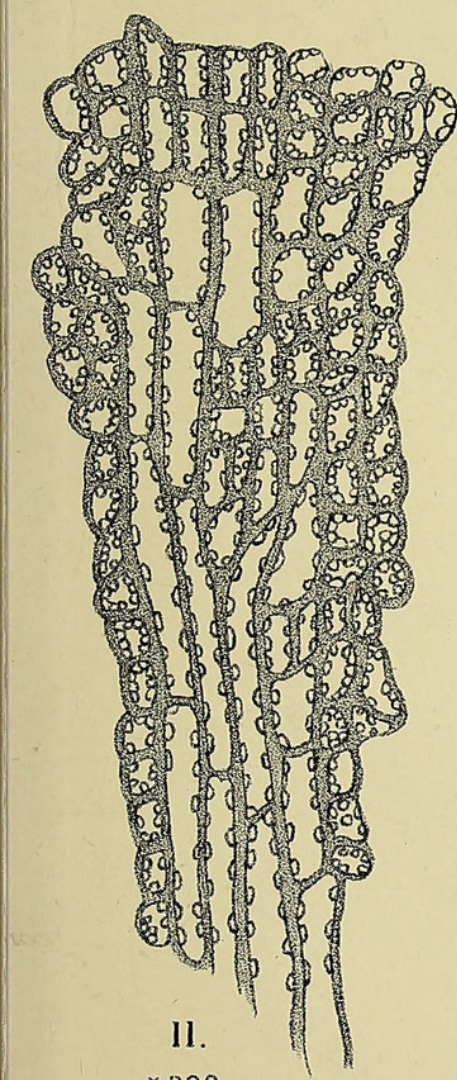

$\times 200$

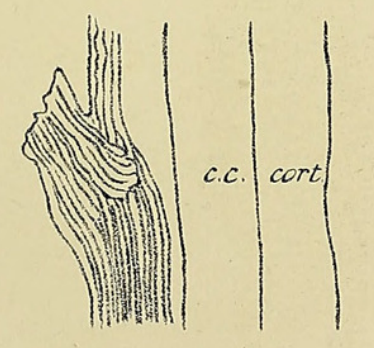

14.

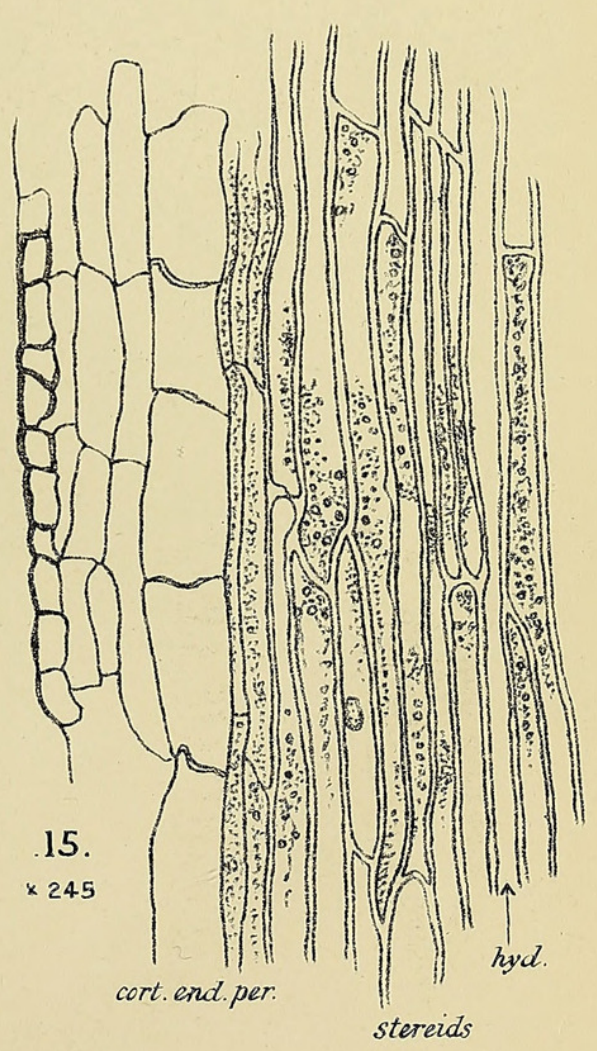

University Press, Oxford. 

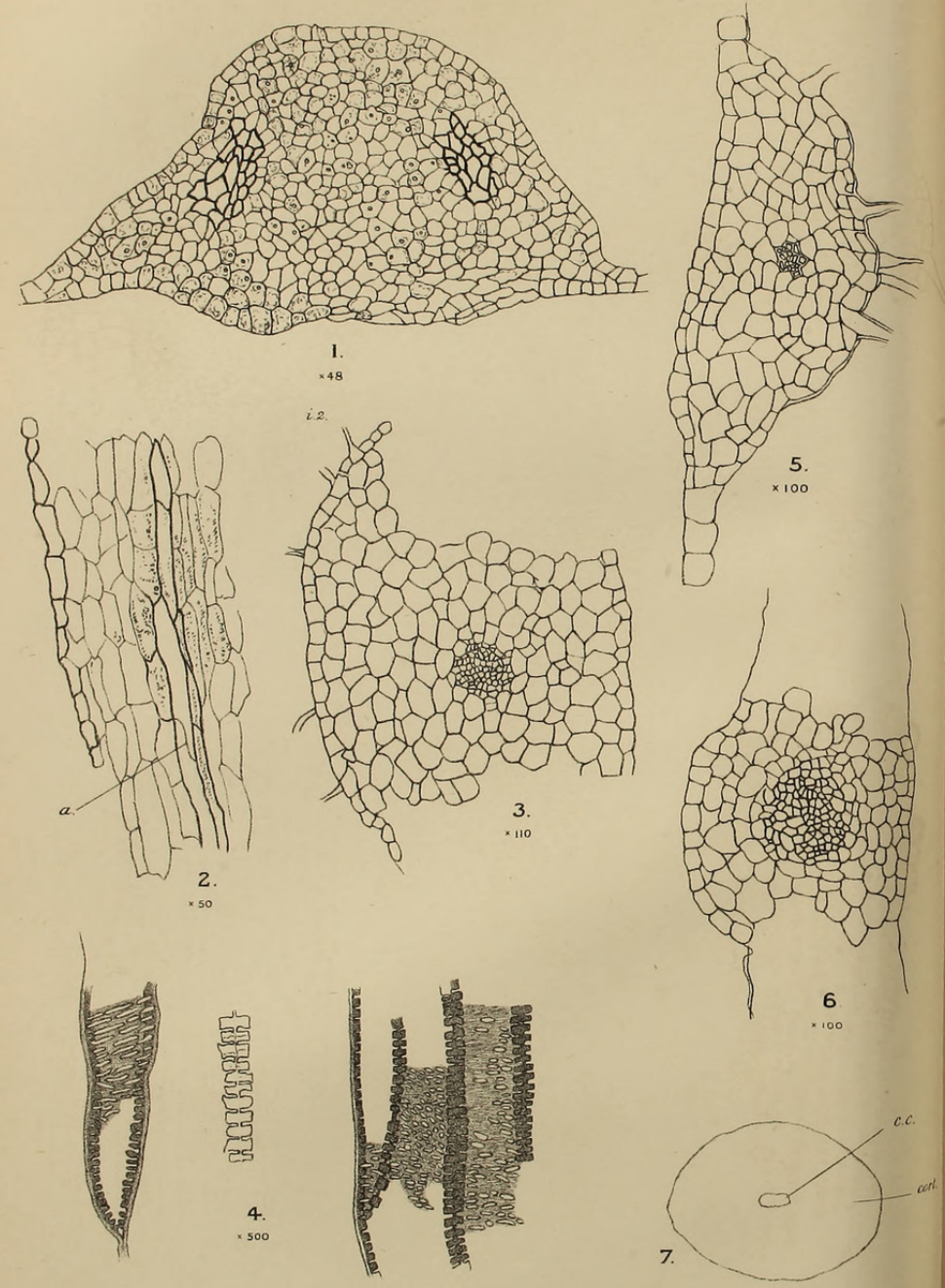

E C del.
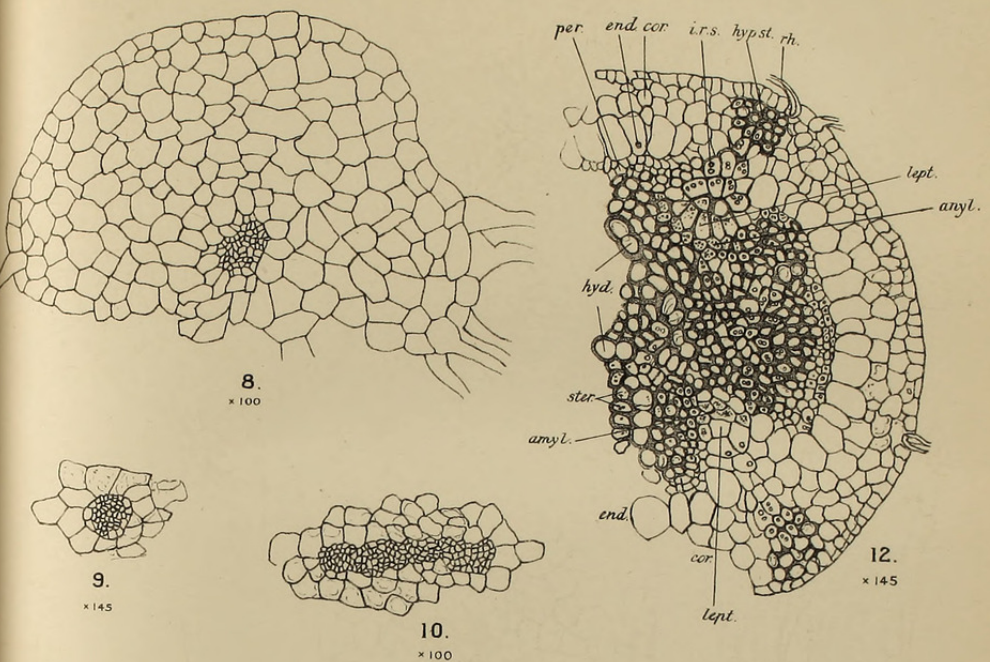

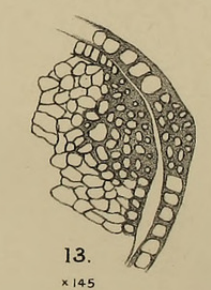

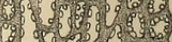

(1)

But $\$$

(6) 21340

a.

.

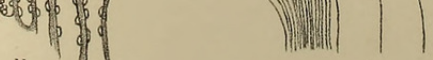

11.
$\times 200$

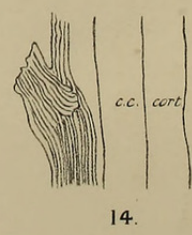

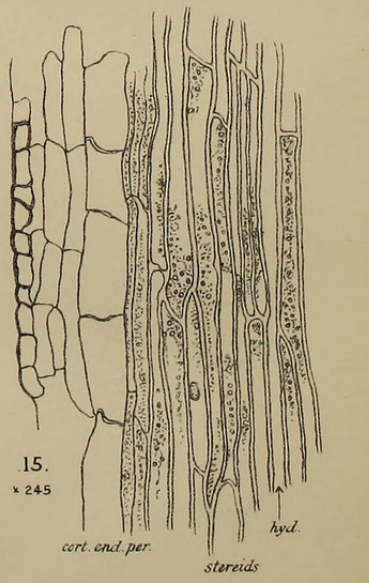

University Press, 0xford 

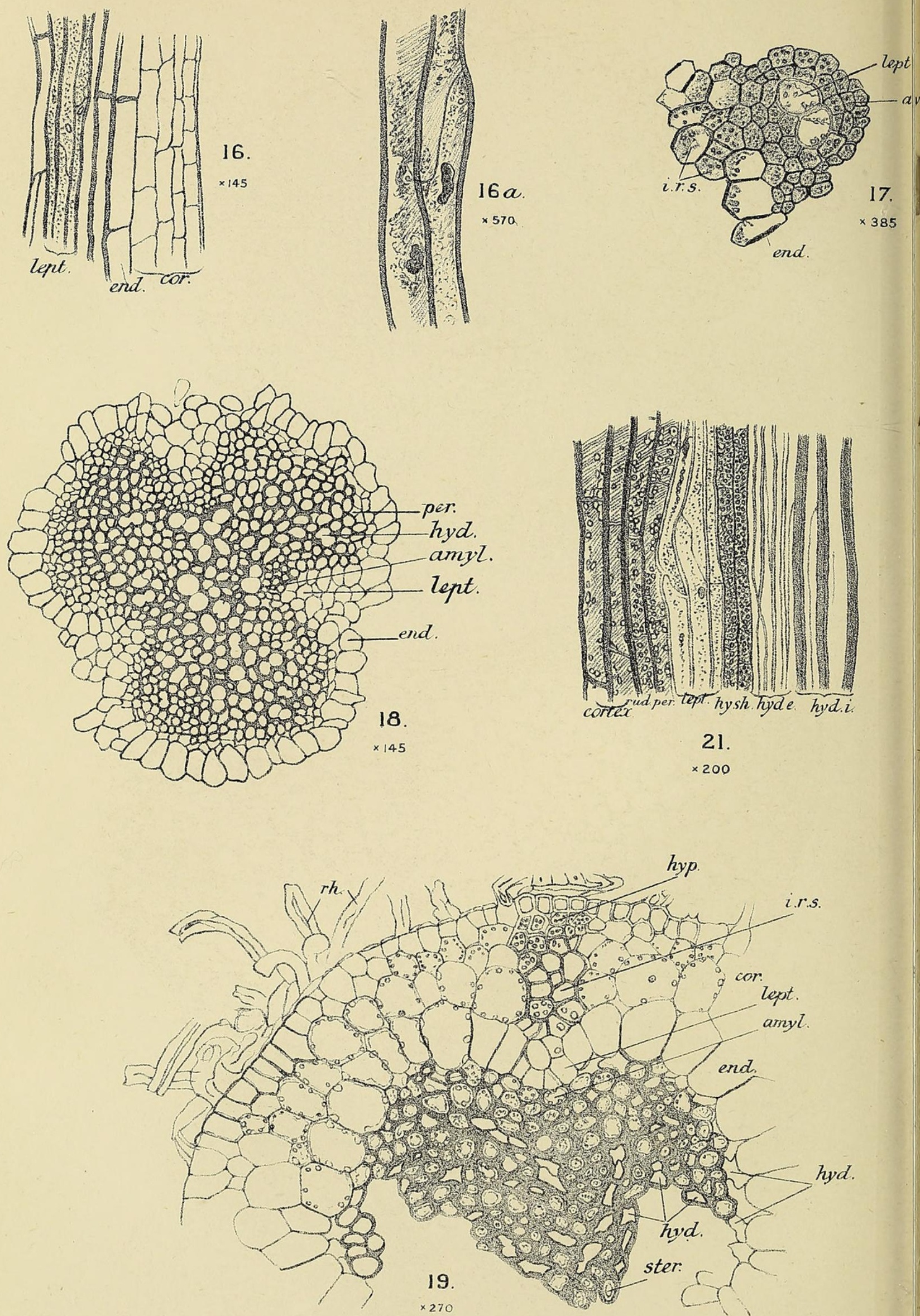
Vol. XV, Pl.II.

VIII
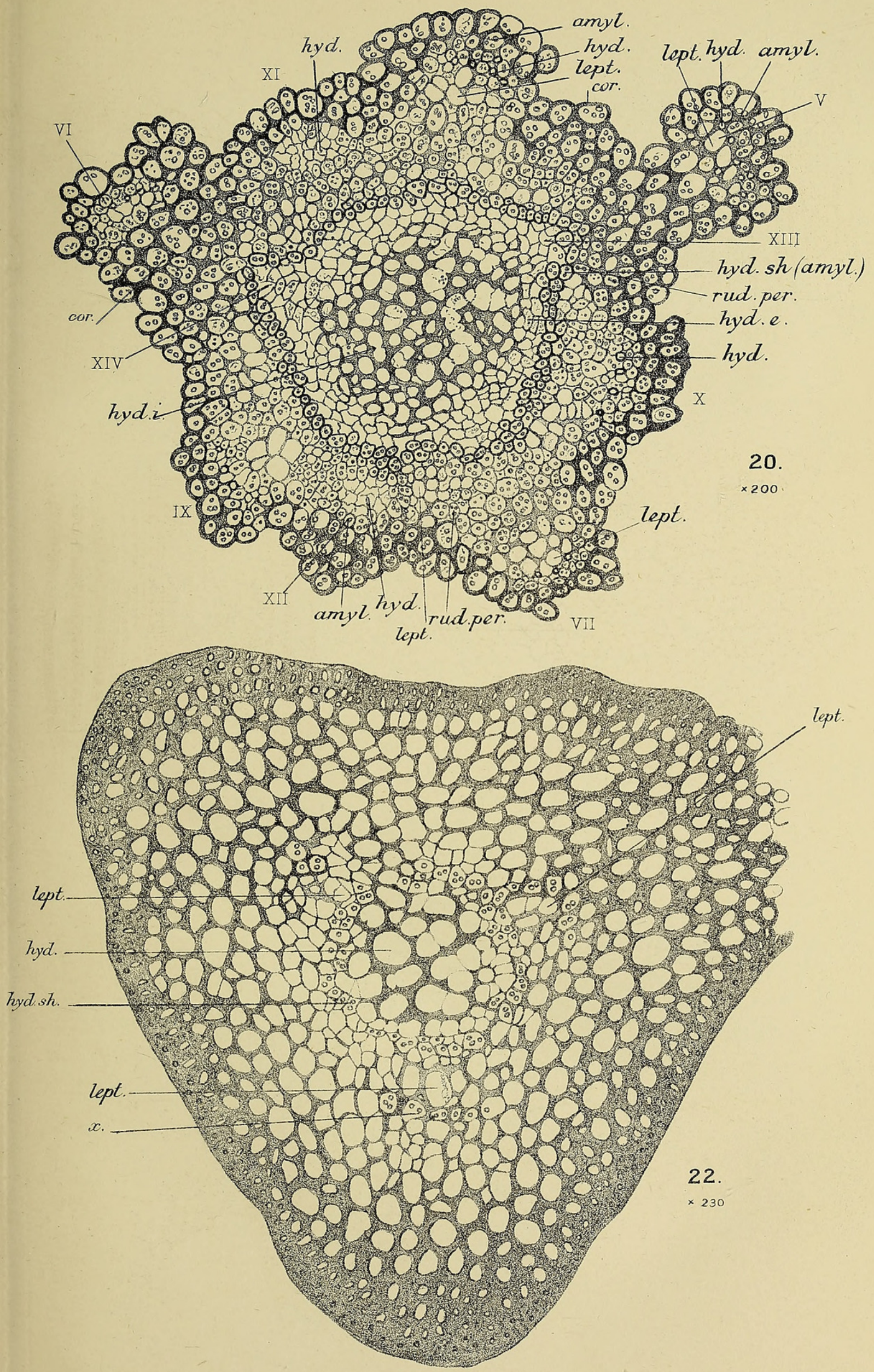

University Press, 0xford. 

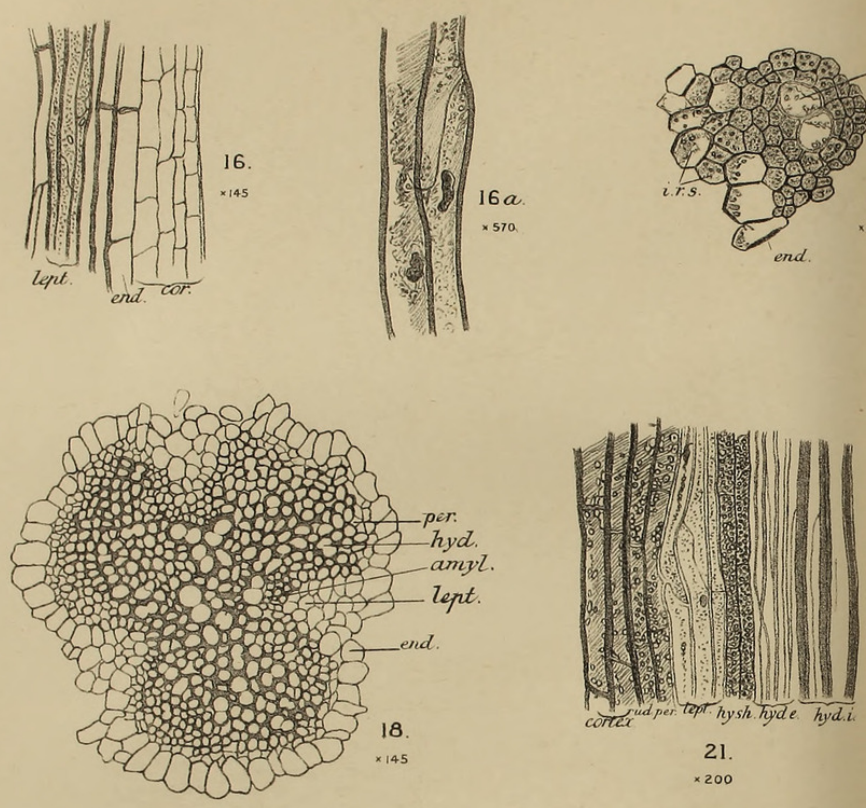

21.
$\times 200$

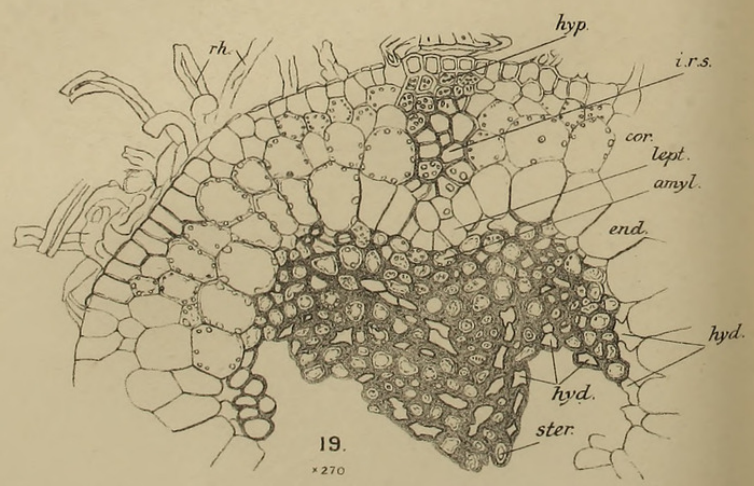

E. C. del.

TANSLEY \& CHICK - CONDUCTING SYSTEM OF BRYOPHYTES
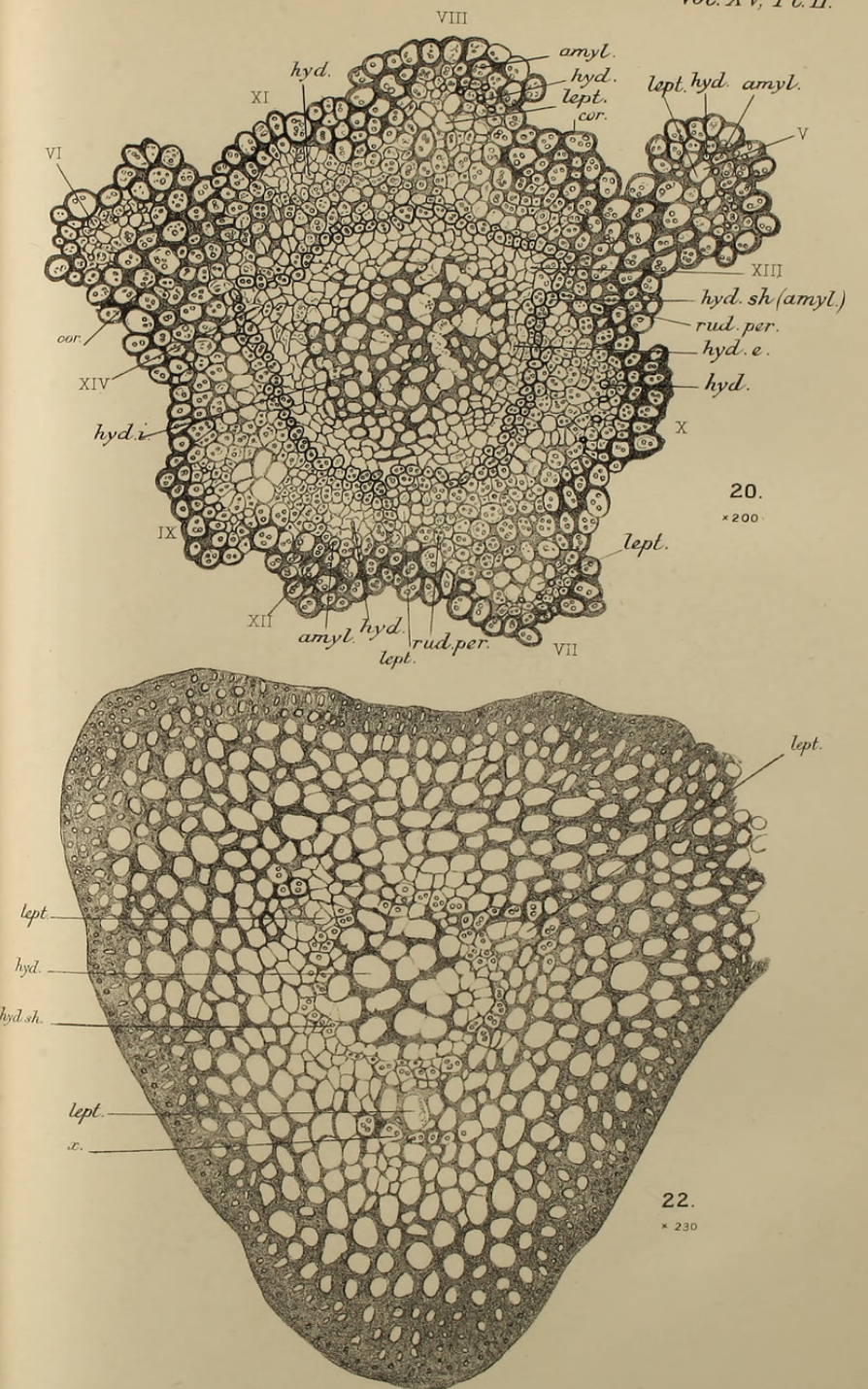

University Press, 0xford 


\section{$2 \mathrm{BHL}$ Biodiversity Heritage Library}

Tansley, A. G. and Edith Chick. 1901. "Notes on the conducting tissue-system in Bryophyta." Annals of botany 15, 1-38.

https://doi.org/10.1093/oxfordjournals.aob.a088805.

View This Item Online: https://www.biodiversitylibrary.org/item/236929

DOI: https://doi.org/10.1093/oxfordjournals.aob.a088805

Permalink: https://www.biodiversitylibrary.org/partpdf/318609

\section{Holding Institution}

Smithsonian Libraries

\section{Sponsored by}

Biodiversity Heritage Library

\section{Copyright \& Reuse}

Copyright Status: Not in copyright. The BHL knows of no copyright restrictions on this item.

This document was created from content at the Biodiversity Heritage Library, the world's largest open access digital library for biodiversity literature and archives. Visit BHL at https://www.biodiversitylibrary.org. 